\title{
Analisis Pengaruh Produk, Harga, Lokasi dan Promosi terhadap Minat Beli Konsumen pada Warung Wedang Jahe (Studi Kasus Warung Sido Mampir di Kota Langsa)
}

\author{
Abdul Latief \\ Fakultas Ekonomi, Universitas Samudra \\ e-mail: latief@unsam.ac.id
}

\begin{abstract}
Abstrak
Penelitian ini dilakukan untuk mengetahui pengaruh produk, harga, lokasi dan promosi terhadap minat beli konsumen pada warung wedang jahe dengan studi pada warung sido mampir yang menjual wedang jahe di kota Langsa. Dari hasil uji regresi berganda dapat dibuat persamaan regresi berganda sebagai berikut: $\mathrm{Y}=1,470+0,168 \mathrm{X}_{1}+0,222 \mathrm{X}_{2}+0,172 \mathrm{X}_{3}+$ $0,113 \mathrm{X}_{4}$. Berdasarkan hasil analisis membuktikan bahwa produk, harga, lokasi dan promosi secara parsial dan simultan berpengaruh signifikan terhadap minat beli konsumen pada warung jahe.
\end{abstract}

Kata Kunci: Produk, Harga, Lokasi, Promosi, Minat Beli

\section{PENDAHULUAN}

Tingginya persaingan usaha dewasa ini sangat menuntut setiap pemilik usaha untuk terus meningkatkan kualitas usahanya kearah yang diharapkan konsumen dengan tidak membuat usahanya merugi karena ditinggalkan konsumen. Perubahan pola pikir konsumen yang dinamis menyebabkan perkembangan usaha yang semakin bersaing. Oleh karena hal tersebut kegiatan pemasaran yang dilakukan oleh setiap organisasi atau usaha yang berbentuk laba atau nirlaba harus dapat memenuhi kebutuhan pola pikir konsumen yang dinamis ke arah tercapainya tujuan organisasi atau usaha yang dijalankan. Para pemasar harus memperhatikan indikator-indikator apa saja yang dapat mendukung hasil usaha dalam mencapai tujuan yang diinginkan. Diantaranya adalah produk, harga, lokasi dan promosi dari usaha yang dijalankannya. Semakin sesuai hal-hal tersebut di mata konsumen dapat menarik konsumen untuk membeli setiap yang dipasarkan oleh usaha tersebut. Setiap usaha dituntut untuk mempertimbangkan konsumen sebagai salah satu faktor terpenting dalam pasar, karena dengan memperhatikan kebutuhan dan keinginan konsumen, setiap usaha dapat memenangkan persaingan dalam pasar sasaran yang semakin terfokus terhadap kepuasan konsumen yang dapat menumbuhkan minat beli konsumen terhadap yang dipasarkan oleh usaha yang ingin mencapai tujuannya.

Kotler (2002) menegaskan bahwa tugas organisasi adalah menentukan kebutuhan, keinginan dan minat dari pasar sasaran dan memberikan kepuasan yang diinginkan secara lebih efektif dan efisien diabndingkan dengan pesaing dengan tetap memelihara atau meningkatkan kesejahteraan masyarakat dan konsumen. Seiring dengan berkembangnya ilmu pengetahuan dan teknologi, masyarakat pada umumnya mengambil keputusan yang praktis, fleksibel dan efisien. Perilaku masyarakat yang modern saat ini telah dinamis menuntut para wirausahawan untuk semakin tanggap 
pada perubahan lingkungan yang ada sebagai konsekuensi dinamika kehidupan untuk menjadikan usaha yang dijalankan berkembang.

Kotler dan Amstrong (2001) menegaskan bahwa kualitas produk merupakan senjata strategis yang potensial untuk mengalahkan pesaing. Jadi hanya usaha dengan kualitas produk paling baik yang akan tumbuh dengan pesat, dan dalam jangka panjang usaha tersebut akan lebih berhasil dari perusahaan yang lain. Jadi suatu usaha dalam mengeluarkan produk sebaiknya disesuaikan dengan kebutuhan dan keinginan konsumen. Dengan begitu maka produk dapat bersaing di pasaran, sehingga menjadikan konsumen memiliki banyak alternatif pilihan produk sebelum mengambil keputusan untuk membeli suatu produk yang ditawarkan. Keunggulan-keunggulan dari produk dapat diketahui oleh konsumen dan bisa membuat konsumen tertarik untuk mencoba dan kemudian akan mengambil keputusan untuk membeli suatu produk tersebut.

Tjiptono (1997) menyatakan bahwa harga adalah jumlah uang (satuan moneter) dan/atau aspek lain (non moneter) yang mengandung utilitas/kegunaan tertentu yang diperlukan untuk mendapatkan suatu produk. Harga merupakan satu-satunya unsur bauran pemasaran yang memberikan pendapatan bagi organisasi. Keputusan mengenai harga tidaklah mudah dilakukan. Disatu sisi, harga yang terlalu mahal dapat meningkatkan laba jangka pendek, tetapi disisi lain akan sulit di jangkau konsumen sedangkan Harga yang rendah atau harga yang terjangkau menjadi pemicu untuk meningkatkan kinerja pemasaran (Ferdinand, 2000). Namun harga juga dapat menjadi indikator kualitas dimana suatu produk dengan kualitas tinggi akan berani dipatok dengan harga yang tinggi pula. Harga dapat mempengaruhi konsumen dalam mengambil keputusan untuk melakukan pembelian suatu produk.

Promosi merupakan salah satu penentu faktor keberhasilan suatu program pemasaran. Betapapun berkualitasnya suatu produk, bila konsumen belum pernah mendengarnya dan tidak yakin bahwa produk itu tidak akan berguna bagi mereka, maka mereka tidak akan pernah membelinya (Tjiptono, 1997). Media promosi yang sering digunakan untuk menyampaikan informasi tentang produk adalah media periklanan. Periklanan merupakan salah satu media yang digunakan perusahaan, bisa diklasifikasikan menurut tujuannya yaitu, untuk memberikan informasi, membujuk dan mengingatkan (Tjiptono, 1997). Inti dari periklanan adalah untuk memasukan sesuatu dalam pikiran konsumen dan mendorong konsumen untuk bertindak atau adanya kegiatan periklanan sering mengakibatkan terjadinya penjualan dengan segera, meskipun banyak juga penjualan terjadi pada waktu mendatang. Dengan demikian, secara umum dapat dikatakan bahwa tujuan periklanan adalah untuk meningkatkan penjualan yang menguntungkan (Dharmmesta, 2007).

\section{TINJAUAN PUSTAKA}

\section{Produk}

Produk dalam prespektif pemasaran adalah segala sesuatu yang dapat ditawar kepada pasar untuk diperhatikan (attention), dimiliki (acquisition), digunakan (use), atau dikonsumsi (consumtion), dan dapat memberikan kepuasan terhadap keinginan dan kebutuhan pasar. Berdasarkan definisi terebut, 
maka yang tergolong dalam pengertian produk antara lain; objek secara fisik (sepeda motor, mobil, pasta gigi, mebel, elektronik, dll), jasa (rumah sakit, kepolisian, Telkom, konsultan, hotel, dll), tempat (taman rekreasi, tempat parker, gedung pertunjukan, dll), organisasi (organisasi politik, LSM, organisasi kampus, yayasan, dll), ide (pemikiran dan konsep).

Beberapa keputusan penting yang terkait dengan variabel produk adalah sebagai berikut:

1. Jenis atau klasifikasi produk yang bagaimana yang harus dipilih oleh oleh perusahaan untuk diproduksi?

2. Atribut apa saja yang dapat dilekatkan pada subuah produk?

3. Bagaimana cara mengembangkan sebuah produk?, dan

4. Bagaimana siklus kehidupan (life cycle) dari sebuah produk dan strategi pemasarannya?

Atribut produk adalah segala sesuatu yang melekat pada sebuah produk yang dapat memberikan nilai tambah pada produk yang bersangkutan dan memberikan ciri khas tersendiri bagi keberadaan produk. Adapun nilai tambah yang dimaksud itu adalah mutu (quality), sifat (future), dan rancangan (design).

1. Mutu produk diartikan sebagai kemampuan produk untuk melaksanakan fungsinya, termasuk keawetan, kenadalan, ketetapan, kemudahan, dipergunakan dan diperbaiki, serta atribut bernilai yang lain. Sebuah produk dapat dikatakan bermutu apabila dapat diukur secara objektif dari sudut pandang pemasaran, serta dari persepsi pembeli. Bagi perusahaan yang ingin meningkatkan daya saingnya, perhatian dan perbaikan terhadap mutu menjadi kunci utama untuk sukses di pasar.

2. Menghasilkan produk yang bermutu harus menjadi budaya bagi perusahaan agar dapat tercipta pencitraan (image) sehingga dapat meningkatkan loyalitas yang tinggi. Perbaikan mutu adalah suatutanggung jawab organisasional. Gaya manajerial yang esensial dan ciri kepemimpinan di dalam mengembangkan budaya yang berorientasi pada mutu mencakup perhatian pada hal-hal yang detail, perencanaan lengkap, pemantauan masalah, standar pribadi yang tinggi, komitmen yang terus menerus terhadap perbaikan mutu, gaya manajemen yang responsive dan partisipatif, dan kepercayaan.

3. Sifat adalah alat bersaing untuk membedakan produk perusahaan dari produk pesaing. Perusahaan dapat menciptakan model model dari tingkat lebih tinggi dengan menambahkan beberapa sifat. Menjadi produsen pertama yang memperkenalkan sifat baru yang dibutuhkan dan dinilai tinggi oleh pelanggan adalah salah satu cara paling efektif untuk bersaing.

4. Rancangan produk adalah proses merancang gaya dan fungsi produk; menciptakan produk yang menarik, mudah, aman, dan tidak mahal untuk dipergunakan dan diservis, serta sederhana dan ekonomis untuk dibuat dan didistribusikan. Dengan semakin meningkatnya persaingan, rancangan akan menawarkan salah satu alat paling ampuh untuk membedakan dan menetapkan posisi produk dan jasa perusahaan. 


\section{Harga}

Kotler dan Keller (2009) menyatakan bahwa harga adalah salah satu elemen bauran pemasaran yang menghasilkan pendapatan, elemen lain menghasilkan biaya. Harga merupakan elemen termudah dalam program pemasaran untuk disesuaikan, fitur produk, saluran dan bahkan komunikasi membutuhkan banyak waktu".

Pendapat lain menurut Tjiptono (2008) menyebutkan bahwa harga merupakan satu-satunya unsur bauran pemasaran yang memberikan pemasukan atau pendapatan bagi perusahaan. Sedangkan menurut Kotler dan Amstrong (2011), pengertian harga adalah sejumlah uang yang dibebankan atas suatu produk atau jasa atau jumlah dari nilai yang ditukar konsumen atas manfaat-manfaat karena memiliki atau menggunakan produk atau jasa tersebut".

Menurut Kotler dan Keller (2009), ada lima tujuan utama dalam menetapkan harga, yaitu:

1. Kemampuan bertahan

Perusahaan mengejar kemapuan bertahan sebagai tujuan utama mereka jika mereka mengalami kelebihan kapasitas, persaiangan ketat, atau keinginan konsumen yang berubah. Selama harga menutup biaya variabel lain dan biaya tetap maka perusahaan tetap berada dalam bisnis

2. Laba saat ini maksimum

Banyak perusahaan berusaha menetapkan harga yang akan memaksimalkan laba saat ini. Perusahaan memperkirakan permintaan dan biaya yang berasosiasi dengan harga relatif dan memilih harga yang menghasilkan laba saat ini, arus kas atau tingkat pengembalian atas investasi maksimum

3. Pangsa Pasar Maksimum

Perusahaan Percaya bahwa semakin tinggi volume penjualan, baiay unit akan semakin rendah dan laba jangka panjang semakin tinggi. Perusahaan menetapkan harga terendah mengasumsikan pasar sensitif terhadap harga.

4. Market Skimming Pricing

Perusahaan mengungkapkan teknologi baru yang menetapkan harga tinggi untuk memaksimalkan memerah di pasar dimana pada mulanya harga ditetapkan tinggi dan secara perlahan turun seiring waktu.

5. Kepemimpinan kualitas produk

Banyak merek berusaha menjadi "kemewahan terjangkau" produk atau jasa yang ditentukan karakternya oleh tingkat kualitas anggapan, selera dan status yang tinggi denga harga yang cukup tinggi agar tidak berada diluar jangkauan konsumen

\section{Lokasi}

Lokasi berkaitan dengan saluran pemasaran antara tempat dan keputusan saluran distribusi. Menurut Tjiptono (2006), place adalah keputusan distribusi yang menyangkut kemudahan akses terhadap jasa bagi para pelanggan potensial. Lokasi berarti berhubungan dengan di mana perusahaan 
harus bermarkas dan melakukan operasi atau kegiatannya (Lupiyoadi, 2013:96). Menurut Lupiyoadi (2013), lokasi juga dikatakan sebagai keputusan yang dibuat perusahaan berkaitan dengan di mana operasi dan stafnya akan ditempatkan.

Faktor-faktor penting yang dipertimbangkan dalam pemilihan lokasi masing-masing perusahaan berbeda. Terjadinya perbedaan dalam pemilihan lokasi ini adalah adanya kaitan dengan kebutuhan masing-masing perusahaan. Adanya perbedaan kebutuhan tersebut membuat perusahaan dalam hal ini menyesuaikan mana yang efektif dan efisien dalam pemilihan tempat atau lokasi yang akan ditetapkan dalam melakukan bisnis. Menurut Tjiptono dalam Syardiansah (2017), ada beberapa pertimbangan dalam menentukan pemilihan lokasi, di antaranya:

1. Akses, yaitu kemudahan untuk menjangkau, misalnya lokasi yang dilalui mudah dijangkau sarana/transportasi umum.

2. Visiabilitas, yaitu lokasi atau tempat yang dapat dilihat dengan jelas dari jarak pandang normal.

3. Lalu lintas (Trafic) menyangkut dua pertimbangan utama berikut:

a. Banyaknya orang yang lalu lalang dapat memberikan peluang besar terhadap terjadinya impulse buying, yaitu keputusan pembelian yang terjadi secara spontan, tanpa perencanaan, dan tanpa melalui usaha-usaha khusus.

b. Kemacetan dan kepadatan lalulintas bisa menjadi hambatan.

\section{Promosi}

Fungsi promosi dalam bauran pemasaran adalah unuk mencapai berbagai tujuan komunikasi dengan setiap konsumen (Cravens, 1994). Komponen komponen bauran promosi (promotion mix) mencakup periklanan, penjualan perorangan, promosi penjualan, dan hubungan masyarakat. Tanggung jawab pemasaran yang terpenting adalah merencanakan dan mengkoordinasikan strategi promosi terpadu dan memilih strategi untuk komponen-komponen promosi.

Promosi menurut Alma dalam Syardiansah (2017) merupakan suatu bentuk komunikasi pemasaran yang berusaha menyebarkan informasi, mempengaruhi, dan atau mengingatkan pasar sasaran atas perusahaan dan produknya agar bersedia menerima, membeli, dan loyal pada produk yang ditawarkan perusahaan yang bersangkutan. Promosi merupakan salah satu variabel dalam bauran pemasaran yang sangat penting dilaksanakan oleh perusahaan dalam memasarkan produk jasa (Lupiyoadi, 2013). Promosi yang baik adalah yang dapat menarik konsumen sebanyak-banyaknya untuk beralih kepada produk atau jasa yang ditawarkan. Kegiatan mempengaruhi konsumen sehingga produk dan jasa yang ditawarkan oleh pemasar telah sesuai dengan kebutuhan dan keinginan mereka juga hal yang paling penting dilakukan dalam melakukan kegiatan promosi.

Menurut Kotler (1997), promotion tools didefinisikan sebagai berikut:

1. Advertising (Periklanan)

Suatu promosi barang atau jasa yang sifatnya non personal dilakukan oleh sponsor yang diketahui. 
2. Personal selling (Penjualan perorangan)

Penjualan perorangan yang dilakukan oleh para wiraniaga yang mencoba dan membujuk untuk melakukan penjualan sekaligus.

3. Sales promotion (Promosi penjualan)

Suatu kegiatan yang dimaksud untuk membantu mendapatkan konsumen yang bersedia membeli produk atau jasa suatu perusahaan

\section{Public relation (Publisitas)}

Suatu kegiatan pengiklanan secara tidak langsung dimana produk atau jasa suatu perusahaan disebarluaskan oleh media komunikasi

\section{Minat Beli}

Minat adalah dorongan untuk memotivasi seseorang melakukan tindakan. Menurut Kotler dan Susanto (2000), Minat beli adalah rangsangan internal yang kuat yang memotivasi tindakan, di mana dorongan ini dipengaruhi oleh stimulus dan perasaan positif akan produk. Sedangkan menurut Schiffman dan Kanuk (2007), minat beli merupakan aktivitas psikis yang timbul karena adanya perasaan dan pikiran terhadap suatu barang atau jasa yang diinginkan..

Assael (2008) menyatakan bahwa minat beli merupakan perilaku yang muncul sebagai respon terhadap obyek yang menunjukan keinginan konsumen untuk melakukan pembelian. Minat beli seseorang berhubungan erat dengan perasaan, ketika seseorang merasa senang dan puas ketika melihat produk atau jasa, maka hal itu akan memperkuat minat beli seseorang (Swastha dan Irawan, 2005). Menurut Ferdinand (2002), minat beli dapat diidentifikasi melalui indikator-indikator sebagai berikut:

1. Minat eksploratif, minat ini menggambarkan perilaku seseorang yang selalu mencari informasi mengenai produk yang diminatinya dan mencari informasi untuk mendukung sifat-sifat positif dari produk tersebut.

2. Minat preferensial, yaitu minat yang menggambarkan perilaku seseorang yang memiliki preferensi utama pada produk tersebut. Preferensi ini hanya dapat diganti jika terjadi sesuatu dengan produk preferensinya.

3. Minat transaksional, yaitu kecenderungan seseorang untuk membeli produk.

4. Minat referensial, yaitu kecenderungan seseorang untuk mereferensikan produk kepada orang lain.

\section{Hipotesis}

Berdasarkan uraian latar belakang dan penelitian terdahulu serta dikaitkan dengan telaah teoritis dan empiris terdahulu, maka hipotesisnya adalah:

1. Produk, harga, lokasi dan promosi secara parsial berpengaruh signifikan terhadap minat beli pada warung jahe. 
2. Produk, harga, lokasi dan promosi secara simultan berpengaruh signifikan terhadap minat beli pada warung jahe.

\section{METODE PENELITIAN}

\section{Populasi dan sampel}

Populasi dalam penelitian ini adalah konsumen yang melakukan pembelian di Warung Sido Mampir. Oleh karena jumlah populasi tidak diketahui, maka untuk menentukan jumlah sampel digunakan rumus Unknow Population sebagai berikut:

$$
n=\left(\frac{Z a / 2 \sigma}{e}\right)^{2}
$$

Keterangan:

$\mathrm{n}=$ jumlah sampel

$\mathrm{Za}=$ ukuran tingkat kepercayaan dengan

$\mathrm{a}=0,05$, maka $\mathrm{Z}=1,96$

$\sigma=$ standar deviasi $=0,25$

$\mathrm{e}=$ standart error atau kesalahan yang dapat ditolerasin $(5 \%)$

Perhitungannya: $=\left(\frac{(1,96)(0,25)}{0,05}\right)^{2}$

$$
=96,04 \approx 100
$$

Berdasarkan perhitungan diatas, maka jumlah sampel dalam penelitian ini adalah 100 orang. Teknik sampling yang digunakan adalah accidental sampling, yaitu siapa saja anggota populasi yang secara kebetulan dijumpai pada saat dilakukan penelitian dan memenuhi kriteria tertentu yaitu pelanggan Warung Sido Mampir sebanyak 100 orang, maka anggota populasi tersebut ditarik sebagai sampel.

\section{Metode Analisis Data}

Metode yang digunakan adalah metode analisis regresi linier berganda yang bertujuan untuk menguji pengaruh atau hubungan antara variabel bebas dengan variabel terikat. Analisis regresi linier berganda pada penelitian ini diformulasikan sebagai berikut:

$Y=a+b_{1} X_{1}+b_{2} X_{2}++b_{3} X_{3}+b_{4} X_{4}$

Keterangan:

$\mathrm{Y} \quad=$ Minat beli

$\mathrm{X}_{1} \quad=$ Produk

$\mathrm{X}_{2} \quad=$ Harga

$\mathrm{X}_{3} \quad=$ Promosi

$\mathrm{X}_{4} \quad=$ Lokasi 
$\mathrm{a} \quad=$ Konstanta

$\mathrm{b} \quad=$ Koefisien regresi

\section{HASIL DAN PEMBAHASAN}

Untuk melihat pengaruh produk, harga, promosi dan lokasi terhadap minat beli konsumen maka digunakan persamaan regresi linear berganda dengan bantuan program SPSS versi 20.0.

Dari tabel 1 hasil uji regresi berganda dapat dibuat persamaan regresi berganda sebagai berikut: $Y=1,470+0,168 X_{1}+0,222 X_{2}+0,172 X_{3}+0,113 X_{4}$,

Dari persamaan regresi tersebut dapat dijelaskan bahwa:

1. konstanta menunjukkan apabila variabel bebas $(\mathrm{X})$ yang terdiri dari produk, harga, promosi dan lokasi bernilai nol, maka konsumen masih memiliki minat beli pada warung wedang jahe sebesar 1,470 .

2. Variabel produk mempunyai pengaruh positif yang berarti apabila produk bernilai satu, maka minat beli konsumen pada warung wedang jahe akan meningkat sebesar 1,470 + 0,168 (1) =1,638 dengan asumsi varibel independen lain bernilai nol.

3. Variabel harga mempunyai pengaruh positif yang berarti apabila harga bernilai satu, maka minat beli konsumen pada warung wedang jahe akan meningkat sebesar $1,470+0,222(1)=1,692$ dengan asumsi varibel independen lain bernilai nol.

4. Variabel promosi mempunyai pengaruh positif yang berarti apabila promosi bernilai satu, maka minat beli konsumen pada warung wedang jahe akan meningkat sebesar 1,470 + 0,172 (1) =1,642 dengan asumsi varibel independen lain bernilai nol.

5. Variabel lokasi mempunyai pengaruh positif yang berarti apabila lokasi bernilai satu, maka minat beli konsumen pada warung wedang jahe akan meningkat sebesar $1,470+0,113(1)=1,583$ dengan asumsi varibel independen lain bernilai nol.

Berdasarkan perhitungan tersebut dapat dilihat bahwa yang memiliki pengaruh terbesar terhadap minat beli konsumen pada warung wedang jahe adalah varibel harga.

\begin{tabular}{l}
\hline \multicolumn{1}{c}{ Variabel } \\
\hline Konstanta \\
Produk \\
Harga \\
Promosi \\
Lokasi \\
\hline Adjusted R. Square \\
F
\end{tabular}

Sig. F
Tabel 1. Hasil Analisis Statistik

\begin{tabular}{ccc}
\hline $\mathrm{B}$ & $\mathrm{t}$ & Sig. $\mathrm{t}$ \\
\hline 1,470 & 2,836 &, 006 \\
, 168 & 1,390 &, 168 \\
, 222 & 2,177 &, 032 \\
, 172 & 1,796 &, 076 \\
, 113 & 1,326 &, 188 \\
$=, 232$ & & \\
$=$ & & \\
$=0,459$ & &
\end{tabular}


Nilai koefisien determinasi Adjusted R Square sebesar 0,232 menunjukkan besarnya pengaruh variabel independen yaitu produk, harga, promosi dan lokasi terhadap minat beli konsumen pada warung wedang jahe sebesar $23,2 \%$. Sedangkan sisanya sebesar $76,8 \%$ diterangkan oleh variabel lain yang tidak diteliti dalam penelitian ini.

\section{Uji t}

Pada uji t dilakukan dengan membandingkan tingkat signifikansi dengan $\alpha(0,05)$. Dengan melihat tabel 1 , nilai t sig variabel produk sebesar 0,168 . Oleh karena nilai t sig 0,168>0,05, maka dapat dinyatakan bahwa variabel produk tidak berpengaruh signifikan terhadap minat beli konsumen pada warung wedang jahe. Nilai t sig variabel harga sebesar 0,032. Oleh karena nilai t sig 0,032 < 0,05, maka dapat dinyatakan bahwa variabel harga berpengaruh signifikan terhadap minat beli konsumen pada warung wedang jahe. Nilai t sig variabel promosi sebesar 0,076. Oleh karena nilai $t$ sig 0,076>0,05, maka dapat dinyatakan bahwa variabel promosi tidak berpengaruh signifikan terhadap minat beli konsumen pada warung wedang jahe. Dan nilai t sig variabel lokasi sebesar 0,188. Oleh karena nilai t sig 0,188 >0,05, maka dapat dinyatakan bahwa variabel lokasi tidak berpengaruh signifikan terhadap minat beli konsumen pada warung wedang jahe.

\section{Uji F}

Sedang uji F dilakukan dengan membandingkan tingkat signifikan dengan $\alpha(0,05)$. Dengan melihat tabel 1 nilai $\mathrm{F}$ sig sebesar 0,000 . Oleh karena nilai $\mathrm{F}$ sig $0,000<0,05$, maka dapat dinyatakan bahwa varibel produk, harga, promosi dan lokasi secara simultan berpengaruh signifikan terhadap minat beli konsumen pada warung jahe.

\section{KESIMPULAN DAN SARAN}

Berdasarkan hasil penelitian yang telah dilakukan dapat ditarik kesimpulan sebagai berikut:

1. Dari hasil uji regresi berganda di peroleh persamaan $Y=1,470+0,168 X_{1}+0,222 X_{2}+0,172 X_{3}+$ $0,113 \mathrm{X}_{4}$ yang berarti konsumen memiliki minat beli pada warung wedang jahe sebesar 1,470 apabila variabel independen bernilai nol.

2. Nilai $R$ sebesar 0,512 berada antara angka 0 dan 1 , artinya variabel independen $(\mathrm{X})$ memiliki hubungan positif terhadap variabel dependen $(\mathrm{Y})$ dan berbanding searah. Sedangkan nilai koefisien determinasi Adjusted $\mathrm{R}$ Square sebesar 0,232 menunjukkan besarnya pengaruh variabel independen yaitu produk, harga, promosi dan lokasi terhadap minat beli konsumen pada warung wedang jahe sebesar $23,2 \%$. Sedangkan sisanya sebesar $76,8 \%$ diterangkan oleh variabel lain yang tidak diteliti dalam penelitian ini.

3. Hasil uji t menunjukkan nilai t sig variabel produk $0,168>0,05$, maka tidak berpengaruh signifikan terhadap minat beli konsumen pada warung wedang jahe. Nilai $t$ sig variabel harga $0,032<0,05$, maka tidak berpengaruh signifikan terhadap minat beli konsumen pada warung wedang jahe. Nilai $t$ 
sig variabel promosi $0,076>0,05$, maka tidak berpengaruh signifikan terhadap minat beli konsumen pada warung wedang jahe. Nilai t sig variabel lokasi $0,188>0,05$, maka tidak berpengaruh signifikan terhadap minat beli konsumen pada warung wedang jahe.

4. Nilai $\mathrm{F}$ sig sebesar 0,000 . Oleh karena nilai $\mathrm{F}$ sig $0,000<0,05$, maka dapat dinyatakan bahwa varibel produk, harga, promosi dan lokasi secara simultan berpengaruh signifikan terhadap minat beli konsumen pada warung jahe.

\section{REFERENSI}

Arikunto, Suharsimi. 2012. Prosedur Penelitian Suatu Pendekatan Praktik. Jakarta: Rineka Cipta.

Assael, H. 2008. Consumer behavior and marketing action. Boston: Wadsworth, Inc.

Ferdinand, A. 2002. Pengembangan minat beli merek ekstensi. Semarang: Badan Penerbit Universitas Diponegoro.

Ghozali, I. 2006. Aplikasi Analisis Multivariate Dengan Program SPSS. Edisi II. Semarang: Badan Penerbit Universitas Diponegoro.

Kotler, Philip., dan G Armstrong. 2008. Prinsip - Prinsip Pemasaran Jilid 1. Edisi Keduabelas. Dialih bahasakan oleh Bahasa Bob Sabran. Jakarta: Penerbit Erlangga. dan Kevin, Lane Keller. 2009. Manajemen Pemasaran. Edisi Ketigabelas. Jilid 1. Dialih bahasakan oleh Bob Sabran. Jakarta: Penerbit Erlangga.

Lupiyoadi, Rambat. 2013. Manajemen Pemasaran Jasa. Edisi Ketiga. Jakarta: Salemba. , dan A. Hamdani. 2008. Manajemen Pemasaran Jasa. Jakarta: Salemba Empat.

Schiffman, Leon., dan Lesslie, Lazar Kanuk. 2007. Perilaku Konsumen. Edisi Ketujuh. Dialihbahasakan oleh : Zoelkifli Kasip. Jakarta: PT. Indeks.

Sugiyono. 2008. Metodologi Penelitian Bisnis. Edisi Revisi. Bandung: Alfabeta.

Swashta, Basu., dan Irawan. 2008. Manajemen Pemasaran Modern. Yogyakarta: Liberty Offet. Tjiptono, Fandy. 2006. Pemasaran Jasa. Edisi Pertama. Malang: Bayumedia Pubhlishing. 2004. Asas - asas marketing. Yogyakarta: Penerbit Liberty. \& Irawan. 2005. Manajemen pemasaran modern. Yogyakarta: Penerbit Liberty.

Syardiansah. 2017. Pengaruh Fasilitas, Harga, Lokasi dan Promosi terhadap Keputusan Sewa Lapangan Futsal oleh Mahasiswa. Jurnal Samudra Ekonomi dan Bisnis. Vol. 8. Hal. 681-683

Bulan, T. P. L., Fazrin, K., \& Rizal, M. 2017. Pengaruh Label Halal dan Bonus dalam Kemasan terhadap Keputusan Pembelian pada Produk Kinder Joy pada Masyarakat Kota Langsa. Jurnal Manajemen \& Keuangan, 6(2), 729-739. https://doi.org/10.5281/zenodo.1320512

Tjiptono, Fandy. 2006. Pemasaran Jasa. Edisi Pertama. Malang: Bayumedia Pubhlishing. 